WE is primarily a clinical diagnosis. Response to treatment may be diagnostic. The sensitivity and specificity of serum thiamine level in symptomatic patients is unclear, as the blood level may not reflect the brain thiamine level. A normal blood thiamine level, as in our patient, does not exclude the possibility of WE with $\mathrm{MRI}$ findings [5]. MRI is more sensitive than CT in WE [6]. In conclusion, all at-risk patients with undiagnosed altered mental status, oculomotor disorders, or ataxia must be evaluated for WE. Further studies are needed for examining the possible role of chemotherapeutics in the development of WE.

Keywords: Wernicke's encephalopathy, Thiamine deficiency, Pediatric leukemia

Anahtar Sözcükler: Wernicke ensefalopatisi, Tiamin eksikliği, Pediatrik lösemi

Conflict of Interest: The authors of this paper have no conflicts of interest, including specific financial interests, relationships, and/or affiliations relevant to the subject matter or materials included.

\section{References}

1. Solmaz $S$, Gereklioğlu Ç, Tan $M$, Demir Ş, Yeral $M$, Korur A, Boğa $C$ Özdoğu H. A rare complication developing after hematopoietic stem cell transplantation: Wernicke's encephalopathy. Turk J Hematol 2015;32:367370.

2. Park SW, Yi YY, Han JW, Kim HD, Lee JS, Kang HC. Wernicke's encephalopathy in a child with high dose thiamine therapy. Korean J Pediatr 2014;57:496499.

3. Parkin AJ, Blunden J, Rees JE, Hunkin NM. Wernicke-Korsakoff syndrome of nonalcoholic origin. Brain Cogn 1991;15:69-82.

4. Beh SC, Frohman TC, Frohman EM. Isolated mammillary body involvement on MRI in Wernicke's encephalopathy. J Neurol Sci 2013;334:172-175.

5. Davies SB, Joshua FF, Zagami AS. Wernicke's encephalopathy in a nonalcoholic patient with a normal blood thiamine level. Med J Aust 2011;194:483-484.

6. Elefante A, Puoti G, Senese R, Coppolo C, Russo C, Tortoro F, de Divitiis O, Brunetti A. Non-alcoholic acute Wernicke's encephalopathy: role of MRI in non typical cases. Eur J Radiol 2012;81:4099-4104.

\title{
Comment: In Response to "Megaloblastic Anemia with Ring Sideroblasts is not Always Myelodysplastic Syndrome"
}

\author{
Yorum: "Halka Sideroblastlı Megaloblastik Anemi Her Zaman Miyelodisplastik Sendrom \\ Olmayabilir"e Yanıt
}

\author{
Smeeta Gajendra \\ Medanta-the Medicity, Department of Pathology and Laboratory Medicine, Gurgaon, India
}

To the Editor,

I read the letter "Megaloblastic Anemia with Ring Sideroblasts is not Always Myelodysplastic Syndrome" by Narang et al., recently published in this journal [1]. The manuscript is well written with a description of a very informative case of megaloblastic anemia with ring sideroblasts in a young female of 18 years old. Ring sideroblasts are associated with abnormal expression of several genes of heme synthesis or mitochondrial iron processing [2]. After exclusion of non-neoplastic causes of ring sideroblasts such as congenital/hereditary sideroblastic anemia and acquired reversible sideroblastic anemia (drugs, toxins, or nutritional deficiency), myelodysplastic syndrome (MDS) can be strongly suspected, particularly in elderly patients. The presence of ring sideroblasts alone is not sufficient for a diagnosis
MDS; the presence of refractory cytopenia(s) is a prerequisite. Refractoriness can only be established after exclusion of secondary causes, most importantly nutritional deficiencies. After that, a complete evaluation of the erythroid, myeloid, and megakaryocytic lineages of bone marrow is essential. At least 15\% ring sideroblasts are required for the diagnosis of MDS with ring sideroblasts (MDS-RS) in cases lacking mutations in the spliceosome gene SF3B1. SF3B1 mutations are found in $60 \%-80 \%$ of patients with refractory anemia with ring sideroblasts (RARS) or RARS with thrombocytosis (RARS-T) and are associated with favorable prognosis [3]. In the recent World Health Organization (WHO) 2016 classification, cases with ring sideroblasts and multilineage dysplasia without excess blasts or isolated del (5q) abnormality are categorized as MDS-RS. Recent 
studies have shown that the percentage of ring sideroblasts in MDS is not prognostically important. Thus, in the revised WHO classification, a diagnosis of MDS-RS may be made even in the presence of only 5\% of ring sideroblasts in cases with SF3B1 mutation. MDS-RS cases will be subdivided into cases with single lineage dysplasia (previously classified as RARS) and cases with multilineage dysplasia (previously classified as refractory cytopenia with multilineage dysplasia). Furthermore, RARS-T has been accepted as an entity and termed MDS/ myeloproliferative neoplasm (MPN) with ring sideroblasts and thrombocytosis (MDS/MPN-RS-T) in the 2016 classification. Unlike MDS-RS, the number of ring sideroblasts required for a diagnosis of MDS/MPN-RS-T is 15\%, irrespective of the presence or absence of a SF3B1 mutation [4]. As described in the case of Narang et al., in a young female of 18 years old without a history of persistent refractory cytopenia(s), a diagnosis of MDS can only be established after exclusion of secondary causes such as nutritional deficiencies [1]. An adequate trial with hematinics (vitamin B12, folic acid, and pyridoxine) is needed in such cases. After exclusion of secondary causes, if cytopenia(s) still persists, a repeat bone marrow examination with cytogenetic and molecular studies can be considered to establish the diagnosis of a clonal hematopoietic disease such as MDS or MDS/MPN.

Keywords: Refractory anemia with ring sideroblasts, RARS with thrombocytosis, Myelodysplastic syndrome/myeloproliferative neoplasm with ring sideroblasts and thrombocytosis
Anahtar Sözcükler: Halka sideroblastlı refrakter anemi, Trombositoz ile birlikte RARS, Halka sideroblast ve trombositoz ile birlikte miyelodisplastik sendrom/miyeloproliferatif neoplazi

Conflict of Interest: The authors of this paper have no conflicts of interest, including specific financial interests, relationships, and/or affiliations relevant to the subject matter or materials included.

\section{References}

1. Narang NC, Kotru M, Rao K, Sikka M. Megaloblastic anemia with ring sideroblasts is not always myelodysplastic syndrome. Turk J Hematol 2016;33:358-359.

2. Cazzola $M$, Invernizzi R. Ring sideroblasts and sideroblastic anemias. Haematologica 2011;96:789-792.

3. Papaemmanuil E, Cazzola M, Boultwood J, Malcovati L, Vyas P, Bowen D, Pellagatti A, Wainscoat JS, Hellstrom-Lindberg E, Gambacorti-Passerini C, Godfrey AL, Rapado I, Cvejic A, Rance R, McGee C, Ellis P, Mudie $\sqcup$, Stephens PJ, McLaren S, Massie CE, Tarpey PS, Varela I, Nik-Zainal S, Davies HR, Shlien A, Jones D, Raine K, Hinton J, Butler AP, Teague JW, Baxter EJ, Score J, Galli A, Della Porta MG, Travaglino E, Groves M, Tauro S, Munshi NC, Anderson KC, El-Naggar A, Fischer A, Mustonen V, Warren AJ, Cross NC, Green AR, Futreal PA, Stratton MR, Campbell PJ; Chronic Myeloid Disorders Working Group of the International Cancer Genome Consortium. Somatic SF3B1 mutation in myelodysplasia with ring sideroblasts. N Engl J Med 2011;365:1384-1395.

4. Arber DA, Orazi A, Hasserjian R, Thiele J, Borowitz MJ, Le Beau MM, Bloomfield CD, Cazzola M, Vardiman JW. The 2016 revision to the World Health Organization classification of myeloid neoplasms and acute leukemia. Blood 2016;127:2391-2405.

\title{
Therapeutic International Normalized Ratio Monitoring
}

\section{Terapötik Uluslararası Normalleştirilmiş Oran İlemi}

\author{
Beuy Joob1, Viroj Wiwanitkit2 \\ 1Sanitation 1 Medical Academic Center, Bangkok, Thailand \\ ${ }^{2}$ Hainan Medical University, Haikou, China
}

\section{To the Editor,}

The report on "Warfarin dosing and time required to reach therapeutic international normalized ratio in patients with hypercoagulable conditions" was very interesting [1]. Kahlon et al. concluded that "Patients with hypercoagulable conditions require approximately $10 \mathrm{mg}$ of additional total warfarin dose and also require, on average, 2 extra days to reach therapeutic international normalized ratio (INR) as compared to controls."
The big concern in this report regards the technique used for INR measurement. Kahlon et al. did not mention this and might not have noted the problem of measurement of INR in the followup of the patient. The quality control of the measurement is very important and measurements from different laboratory techniques and settings can be a factor leading to error in laboratory results $[2,3]$. It is noted that the local calibration in correcting the variability in INR determination and the difference between batches has to be controlled [4]. 